\title{
Statistical Analysis of Hotel Enterprises and Forecasting Its Development
}

\author{
Natalia BULGARU ${ }^{\star}$, Ioan-Radu PETRARIU ${ }^{\star \star}$, Aura COLAN $^{\star \star \star}$

\begin{abstract}
A B S T R A C T
The article provides a statistical survey of the hotel industry. The positive and negative sides of the operating trend of these enterprises are highlighted using the forecast of the development of hotels and accommodation facilities in Ukraine. The dynamic analysis of the development of the hotel business enterprises is given, presents trends according to the results of the analysis. Based on the experience of the local experience, we can say that the hotel industry is part of the tourist activity, namely the extremely profitable industry of the economy, which is developing rapidly and has considerable potential for further development. This is the reason why the delay in hotel services in Ukraine requires an
\end{abstract} \\ analysis, identification and consideration of market problems and how to solve them.
}

(C) 2019 EAI. All rights reserved.

\section{Introduction}

Ukraine, being a unique country with unique natural and climatic potential, in the long term has all the resources to improve the competitiveness of the economy by using its cultural and natural resources. But to meet all the needs of a tourist, of a businessman, it is necessary to ensure a comfortable stay, the high quality service, that is, to create an atmosphere of hospitality. This is only possible on the basis of a statistical analysis of the development of enterprises in the hospitality sector, an assessment of the peculiarities of the functioning of the hotel, to determine the trend of their development in the future.

\section{Analysis of recent research and publications}

Significant contribution to the development of statistical tools and statistical and economic analysis of enterprise management. The theoretical, methodological, and organizational structure of these problems have been reflected in the scientific works of Z. Baranik, O. Vasechko, E. Halytska, S. Gerasimenko, A. Erina, S. Semikolenova, Y. Tsal-Tsalko, and others. But the topic of statistical analysis and forecasting the development of hotel business remains poorly understood and needs further study (Lozova 0.,2017).

\section{Formulation of research's objectives}

The purpose of this article is to provide statistical analysis and forecasting of the development of the hotel industry. In the context of the study the following methods were used: observation and comparison, theoretical generalization, grouping, comparing, and dynamics; the method of extrapolation was used in order to predict the development of the tourism industry in the near future, and it has been used a graphical method to illustrate the results of the study (Ovcharenko LV, 2015).

The term "hotel "comes from the latin hostel and anglo-Saxon hospitality, which means" hospitality", as well as the old French hospice, meaning "guest". Therefore, the hotel industry is called the hospitality industry. According to M. V. Zaikino, "hotel companies in the tourism and hospitality industry perform key functions, develop and offer consumers a product of broad hotel's services, which promotes all sectors and elements of tourism and hospitality" (Ostapenko, Ja.O.,2015).

The main goal of the hotel business is to provide impeccable service. To achieve its goal, hotel companies need to settle and solve the following tasks (Marcin T.O, Burak T.V., 2013):

* To make efforts for excellence by introducing the latest technologies for hotel services and hotel management (including energy conservation), as well as non-standard approaches to meet customer's needs and staff efficiency in the best way possible;

* To create an atmosphere of hospitality based on the needs and comfort of guests;

* To approach services and activities to international standards; 
To maintain the "price - quality" ratio".

Currently, the global hotel industry has about 350,000 comfortable hotels with more than 14 million rooms (26 million beds), with the number of rooms growing annually by an average of 3-4\% a year over the past 20 years, seeing the dynamics of the significant growth of accommodation facilities for tourists. Individual indicators for the development of the hotel industry by country are analyzed in Table 1.

Table 1. Dynamics of the hotel industry's development by country

\begin{tabular}{|c|c|c|}
\hline Indicator of the hotel in & ustry's development & Countries \\
\hline \multirow{7}{*}{ The power of the hotel fund } & 3,5 milions rooms & United States of America \\
\hline & 1,65 milions rooms & Japan \\
\hline & 1 milion rooms & Italy \\
\hline & 0,5 milion rooms & France, Spain, England, China, Australia \\
\hline & 0,3 milion rooms & Austria, Mexico, Canada, Greece \\
\hline & $\begin{array}{c}0,15-0,23 \text { milion } \\
\text { rooms }\end{array}$ & Thailand, Russia, Indonezia, Turkey \\
\hline & $\begin{array}{l}\text { Less than de } 0,15 \\
\text { milion rooms }\end{array}$ & Switzerland, Brazil, Argentina \\
\hline \multicolumn{2}{|c|}{ Hotel fund growth rate } & $\begin{array}{l}\text { Turkey, China, Malaysia, Singapore, } \\
\text { Morocco, Spain, Germany, Argentina }\end{array}$ \\
\hline \multirow{4}{*}{$\begin{array}{c}\text { The largest international tourist } \\
\text { exchange }\end{array}$} & $\begin{array}{l}\text { More than } 3 \text { milion } \\
\text { hotels }\end{array}$ & Italy \\
\hline & $\begin{array}{c}\text { More than } 2 \text { milion } \\
\text { hotels }\end{array}$ & Germany, France, Spain, England \\
\hline & $\begin{array}{l}900 \text { thousands } \\
\text { of beds }\end{array}$ & Austria, Canada, Mexico \\
\hline & $\begin{array}{l}550 \text { thousands } \\
\text { of beds }\end{array}$ & Greece, former Yugoslav countries \\
\hline \multicolumn{2}{|c|}{ The highest rates of hotel construction } & $\begin{array}{c}\text { China, Turkey, Morocco, Singapore, } \\
\text { Malaysia }\end{array}$ \\
\hline \multicolumn{3}{|c|}{$\begin{array}{c}\text { Global indicators of the hotel industry's } \\
\text { development }\end{array}$} \\
\hline \multicolumn{2}{|c|}{ Number of hotels, thousands of units } & $\mathbf{3 0 7 , 0 7}$ \\
\hline \multicolumn{2}{|c|}{ Number of hotel rooms, million units } & 11,1 \\
\hline \multicolumn{2}{|c|}{ Hotel roomsgrowth's rate,\% } & 10-15 \\
\hline \multicolumn{2}{|c|}{ Number of hotel staff, millions of people } & 11,2 \\
\hline \multicolumn{2}{|c|}{ Average global hotel load,\% } & 67,7 \\
\hline \multicolumn{2}{|c|}{ Average global income per room USD } & 84,4 \\
\hline
\end{tabular}

Source: prepared by author based0vcharenko L.V. Development of hotel business: modern world trends №1p. 120-126

In 2017, the Ukrainian hotel industry numbered 2,644 hotels and similar accommodation facilities, of which 1,523 were hotels (57.6\%). The room number of the hotel fund for 2017 was 69,237 rooms, whose living space was 1 604, 8 thousand square meters, which housed 135518 seats, accommodating 3814201 people and received an income from hotel services of 3404439 UAH (O.V. Balakhonova, T.M. Dyachuk, MV Zaikina 2011).

Table 1.2. Dynamics of the Ukrainian hotel industry's development in 2014-2017

\begin{tabular}{|c|c|c|c|c|c|c|}
\hline \multirow[b]{2}{*}{ Year } & \multicolumn{2}{|c|}{$\begin{array}{c}\text { Number of Enterprisesof hotel } \\
\text { type, units }\end{array}$} & \multicolumn{2}{|c|}{ Number of rooms, units } & \multicolumn{2}{|c|}{$\begin{array}{l}\text { Space of all rooms, thousands of } \\
\text { square meters }\end{array}$} \\
\hline & \begin{tabular}{|c|}
$\begin{array}{c}\text { Absolute value of } \\
\text { the indicator, } \\
\text { units }\end{array}$ \\
\end{tabular} & $\begin{array}{l}\text { Growth } \\
\text { rate,\% }\end{array}$ & $\begin{array}{c}\text { Absolute value of } \\
\text { the indicator, } \\
\text { units }\end{array}$ & $\begin{array}{l}\text { Growth } \\
\text { rate, } \%\end{array}$ & \begin{tabular}{|c|} 
Absolute value of the \\
indicator, thousands \\
$\mathrm{m} 2$
\end{tabular} & Growthrate,\% \\
\hline 2014 & 3162 & 182,67 & 76986 & 96,43 & 1624,6 & 95,53 \\
\hline 2015 & 3144 & 99,43 & 81441 & 105,79 & 1805,3 & 111,12 \\
\hline 2016 & 3582 & 113,93 & 89685 & 110,12 & 1996,1 & 110,57 \\
\hline 2017 & 2644 & 73,81 & 69237 & 77,2 & 1604,8 & 80,4 \\
\hline
\end{tabular}

Source: Statistics Service of Ukraine, interpreted by the author http://www.ukrstat.gov.ua/

Hospitality enterprises operate mainly in resort areas or business regions of Ukraine. The distribution of Ukrainian Hotel Enterprises by Regions is shown in Fig. 1.1 


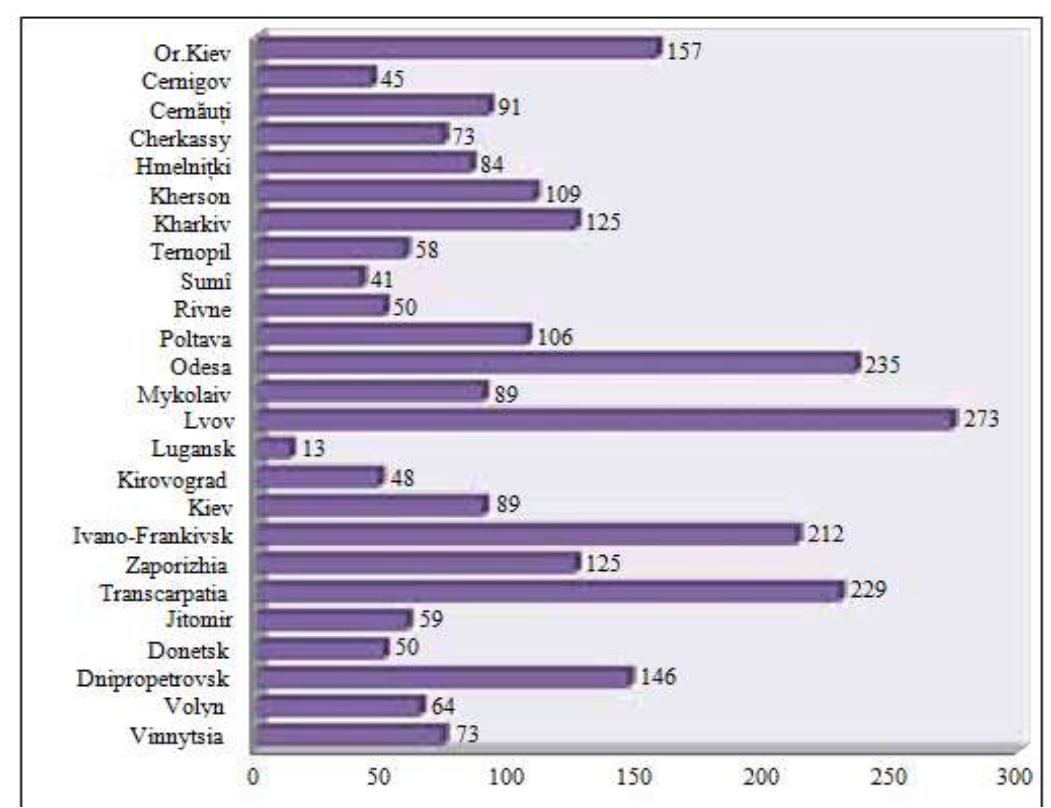

Figure 1. Distribution of enterprises in the hotel sector of Ukraine in 2017 by regions Source: Statistics Service of Ukraine, interpreted by the author http://www.ukrstat.gov.ua/

The largest number of hotel enterprises are located in Lviv (0.33\%), Odessa (8.89\%), Transcarpathian (8.86\%), Ivano-Frankivsk (8.08\%) and Kiev (5.94). \%). The smallest number of hotel units is located in the Lugansk region: $0.49 \%$ of the total number of hotels. The interesting thing is that hotels are seasonal (in areas not included in active tourist areas, summer is the lowest, in resort areas-summer and winter is the highest). Also, hotel charges throughout the year are usually uneven and on weekdaysweekends decrease, increasing on weekdays at the expense of those on a business trip.

Significant competition for hotel enterprises, including large hotels, is created by individuals business entities, which mainly own small hotels and own private houses and apartments. They offer visitors a full range of basic and additional hotel services at a much lower cost. The share of these enterprises in 2017 was almost 59\% (Fig. 2).

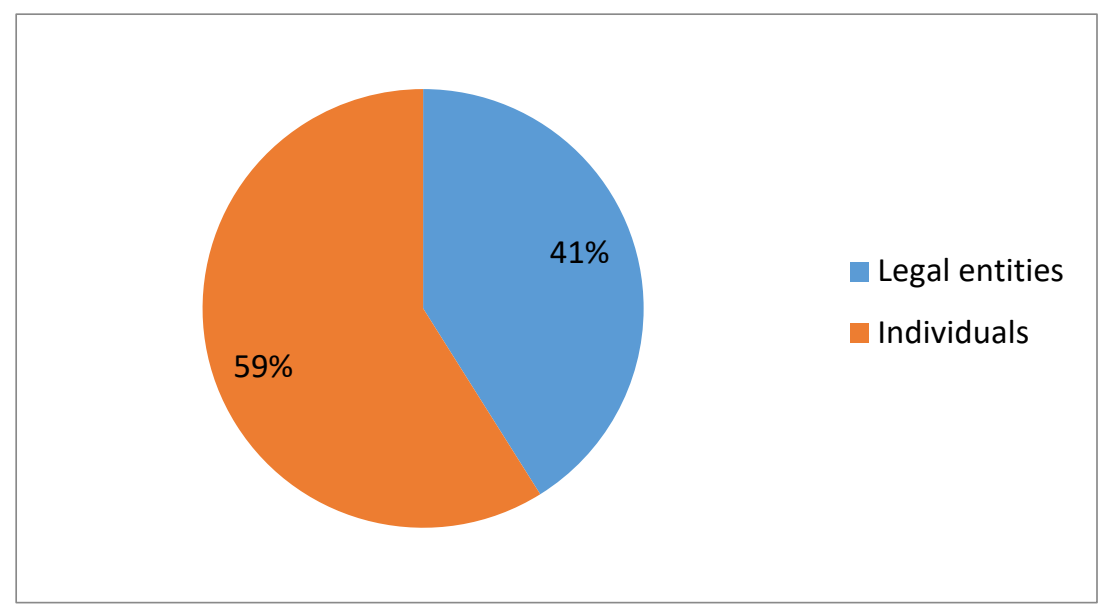

Figure 2. Distribution of hotel enterprises by status

Source: Statistics Service of Ukraine, interpreted by the author http://www.ukrstat.gov.ua/

One of the main trends in the functioning of the hotel industry in Ukraine is the development of hotel enterprises, such as the creation and development of eco-hotels (or green hotels). They are most widespread in recreational or tourist attractions. According to Eric van Dyck, The International Coordinator of the key Green Program, which is one of five projects of the independent international non-governmental organization the foundation for Environmental Education (Papp, V.V.,2015). The environmental performance of hotel is based on 12 key criteria developed by the international committee, and includes environmental management at enterprise, monitoring the usage of water and energy, managing waste, raising environmental awareness among staff and guests, the co-operation with the local community in which it operates the hotel" (Tymchyshyn-Chemerys Yu., 2017). Ukrainian green hotel enterprises that have received green Key certification are listed in Table 3. 
Table 3. Certified Green Key enterprises of Ukraine

\begin{tabular}{|c|c|c|}
\hline Location & $\begin{array}{c}\text { Number of } \\
\text { eco-friendly } \\
\text { hotels }\end{array}$ & $\begin{array}{c}\text { The name of the eco- } \\
\text { hotel }\end{array}$ \\
\hline \multirow{3}{*}{ Kiev } & \multirow{3}{*}{3} & Radisson Blu Hotel \\
\hline & & Rus Accord Hotel \\
\hline & & Baccarat Art Hotel \\
\hline \multirow{3}{*}{ Kiev region } & \multirow{3}{*}{2} & Maison Blanche (Birch) Ecodim \\
\hline & & \\
\hline & & Maison Blanche (Mytnitsa) Ecodim \\
\hline \multirow{3}{*}{ Lviv } & \multirow{3}{*}{3} & Reikartz Dworzec Lviv \\
\hline & & Reikartz Medievale Lviv \\
\hline & & Dniester Premier Hotel \\
\hline Mykolaiv & 1 & Reikartz River Nikolaev \\
\hline Zaporozhye & 1 & Reikartz Zaporizhzhia \\
\hline Dnepropetrovsk & 1 & Reikartz Dnipropetrovsk \\
\hline Kharkov & 1 & Reikartz Kharkiv \\
\hline Transcarpathian region & $\mathbf{1}$ & Ark \\
\hline
\end{tabular}

Source: interpreted by the author Marcin TO, Burak TV Effective approaches to the development of enterprises, industries, complexes

In the world economy there are over 124 green key hotels, eco-hotels in Ukraine make up almost $11 \%$ of the total number of such hotels (Fig. 3).

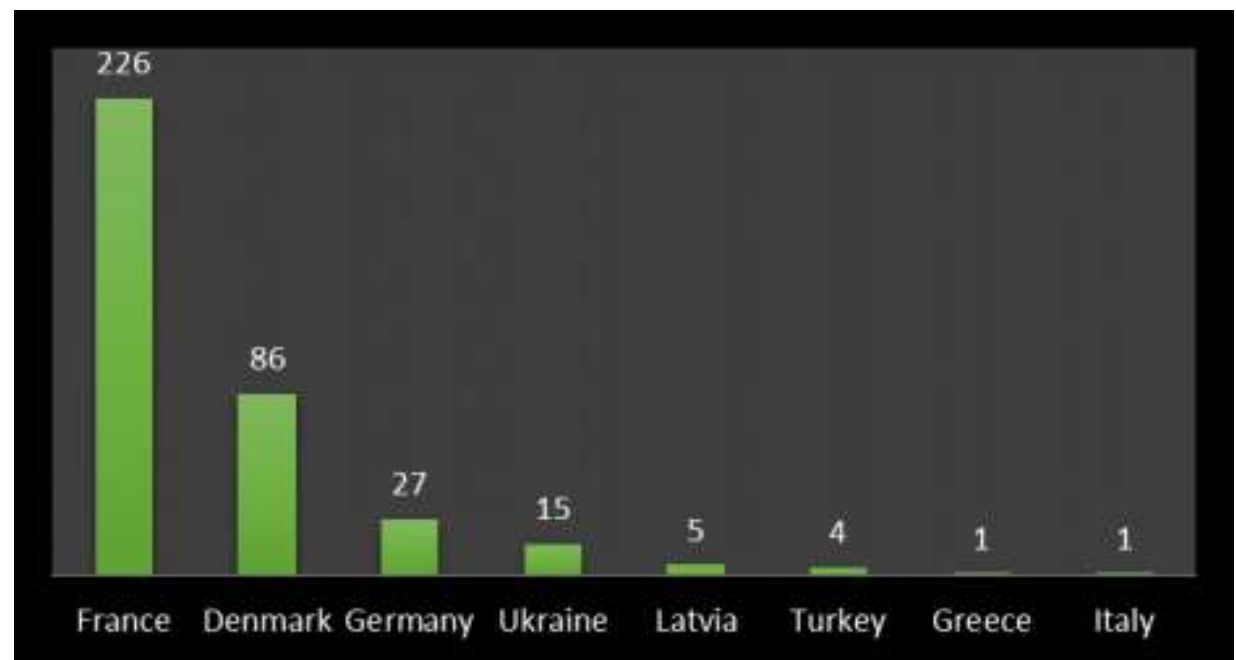

Figure 3. Number of green key certified hotels Source: interpreted by the author

As can be seen from Fig. 4, Ukraine ranks fourth in the number of green hotels in the world. One of the trends in the hotel industry's development in the world is the tendency to form international hotel chains (combining hotels that have centralized management and form a single economic complex). This is a positive situation for the hotel industry in general, and in relation to the regulation of corporate service quality of hotels, knowing the client base of the mark hotels, but the disadvantages of such chains are the competitiveness of small hotels, which are operating in a particular region. International hotel chains operating in Ukraine are presented in Table 4. As Table 4 illustrates, hotel chains are mostly five- and fourstar hotels, located mainly in the city of Kiev, which is economically and financially viable, as a center for the development of business projects and business meetings. 
Table 4. International hotel chains in Ukraine

\begin{tabular}{|c|c|c|c|}
\hline Brand & Stars & $\begin{array}{c}\text { Hotel capacity, } \\
\text { rooms }\end{array}$ & Location \\
\hline Rixos, PRYKARPATTYA & 5 & 769 & $\begin{array}{l}\text { Truskavets, Lviv } \\
\text { region }\end{array}$ \\
\hline Interkontinental, Interkontinental Kiev & 5 & 272 & Kiev \\
\hline Hyatt, Hyatt Regensy Kiev & 5 & 234 & Kiev \\
\hline Rezidor, Radisson SAS Kyiv & 4 & 255 & Kiev \\
\hline Rezidor, Radisson SAS Resort Alushta & 4 & 63 & Alushta \\
\hline Best Western International & 3 & 106 & Sevastopol \\
\hline Rezidor, Radisson Blu Resort, Bukovel & 4 & 252 & $\begin{array}{l}\text { Ivano-Frankivsk } \\
\text { region. }\end{array}$ \\
\hline Accor, IBIS & 3 & 212 & Kiev \\
\hline $\begin{array}{l}\text { Wyndham Hotel Group, Ramada } \\
\text { Donetsk }\end{array}$ & 3 & 165 & Donetsk \\
\hline $\begin{array}{l}\text { Wyndham Hotel Group, Ramada } \\
\text { Lviv }\end{array}$ & 3 & 103 & Lviv \\
\hline $\begin{array}{l}\text { Wyndham Hotel Group, Ramada } \\
\text { Encore Kiev }\end{array}$ & 2 & 264 & Kiev \\
\hline IHG, Holiday Inn Kiev & 4 & 208 & Kiev \\
\hline Park INN by Radisson Donetsk & 4 & 171 & Donetsk \\
\hline $\begin{array}{l}\text { Rezidor, Radisson Blu Hotel } \\
\text { Kiev Podil }\end{array}$ & 4 & 164 & Kiev \\
\hline $\begin{array}{l}\text { Fairmont Raffles International, } \\
\text { Fairmont Grand } \\
\text { Hotel Kyiv }\end{array}$ & 5 & 258 & Kiev \\
\hline
\end{tabular}

Source: interpreted by the author[Electronic resource]. - Access mode: http://nbuv.gov.ua/jpdf/eui 20131 7.pdf.

This is confirmed by LIGABusinessInform news agency, which reports that nine comfortable hotels are planned to open in Kiev by the end of 2020 (Table 5):

Table 5

\begin{tabular}{|llccc|}
\hline \multicolumn{1}{c}{ Hotel name } & \multicolumn{1}{c}{ Operator } & Starry & $\begin{array}{c}\text { Number of } \\
\text { rooms }\end{array}$ & $\begin{array}{c}\text { Opening } \\
\text { year }\end{array}$ \\
\hline Renaissance Kyiv & Marriott International & $4-5$ & 173 & $\mathbf{2 0 2 0}$ \\
\hline Park Inn by Radisson & The Rezidor Hotel Group & 3 & 199 & $\mathbf{2 0 2 0}$ \\
\hline Sofitel & Accor Hotels & 5 & 285 & $\mathbf{2 0 2 0}$ \\
\hline Aloft & Starwood Hotels & 4 & 320 & $\mathbf{2 0 2 0}$ \\
\hline Sheraton Olympiysky & Starwood Hotels & $4-5$ & 190 & $\mathbf{2 0 2 0}$ \\
\hline Azimuth Hotel & Azimuth Hotel & 4 & 235 & $\mathbf{2 0 2 0}$ \\
\hline Sankt Petersburg & - & 4 & 50 & $\mathbf{2 0 2 1}$ \\
\hline Hotel Indigo & Inter Continental & 4 & 240 & $\mathbf{2 0 2 0}$ \\
\hline \hline Voyage & Rosinvest & $\mathbf{3 - 4}$ & $\mathbf{1 6 5}$ & $\mathbf{2 0 2 1}$ \\
\hline
\end{tabular}

Source: interpreted by the author - Access mode: http: // www.liga.net.

\section{Conclusions}

The analysis of the evolution of the number of hotels in Ukraine and in the world, as well as the tendency of the change of the fund's hospitality made it possible to conclude that this sector of economic activity is an area of promising investment, as it develops rates quite fast, determines the level of employment in those areas, it creates the material basis for the development of the tourism industry. But in recent years, enterprises in the hotel industry have developed under negative conditions, in particular, the country's unstable economic and political situation, which leads to a decrease in tourist and business activity, lack of funding, lack of attractive land complexes for hotel construction, long repayment of such projects, and many more. In my opinion, the development of the hotel and Tourist Business Development Program, the search for financial sources and the creation of a favorable investment climate will help to improve the situation.

Studies show that customer satisfaction depends on the hotel's ability to fully meet customers ' needs. In the modern conditions of active development of tourism trips international tourists' needs in terms of basic services and the additional units are growing and becoming more diverse, which has given impetus to the creation of a business hotel vary depending on the level of service and level of comfort. Grouping hotels on these grounds requires, in turn, an appropriate organization the operation of the hotel, service standards 
and a certain pricing policy. It is quite clear that such a diversified offer of hotel services requires a certain systematic characterization, that is, Classification. The classification of the hotel is the determination of the suitability of a particular hotel and its room for certain criteria or standards of Service. Classification refers to the distribution of hotels by level of service, and typology takes into account other modern trends in the development of hotel business.

\section{References}

1. Lozova O. (2017). "Modern development of the hotel industry in Ukraine" - Bulletin of the Kharkov National Technical University of Agriculture named after Petr Vasilenko, 185, 251-259

2. Marcin T.O, Burak T.V. 2013, "Effective approaches to the development of enterprises, industries, complexes " Kuprienko S.V, 2013 $172 p$.

3. O.V. Balakhonova, T.M. Dyachuk, MV Zaikina 2011 " Estimation of prospects of development of economic potential of Ukraine in the XXI century ": international scientific and practical conference, Kyiv Economic Science Center - Part II. - pp. 49-51.

4. Ostapenko, Ja.O. (2015). "Statistical analysis of the hotel industry and prognosis of its development"-Global and national problems of Ukraine, 8, 1216-1221 [in Ukranian].

5. Ovcharenko LV 2015 "Hotel business development: modern world trends " L.V. Ovcharenko, A.V.Ovcharenko, The World of Man, No. 1. P. 120-126.

6. Papp, V.V. (2015). "The role of the hotel industry in the development of tourism in the region".- Scientific bulletin of Uzhhorod university. Series «Economics», 2 (46), 207-212.

7. State Statistics Service of Ukraine [Electronic resource]. - Access mode: http://www.ukrstat.gov.ua.

8. Tashmatova L. They go round: the occupancy rate of hotels has decreased to 30\%, LIGABusinessInform [Electronic resource]. - Access mode: http: // www.liga.net.

9. Tymchyshyn-Chemerys Yu. (2017). "Key concepts and factors of the hotel company's profit" Internauka. Interscience, 3 (25), $147-152$.

10. Бурак Т.В. "Розвиток контрактного управління готельними мережами в Україні" [Електронний ресурс]. - Режим до- ступу : http://nbuv.gov.ua/j-pdf/eui_2013_1_7.pdf. 